AperTO - Archivio Istituzionale Open Access dell'Università di Torino

Mélange concept: redefinition and new classification

This is a pre print version of the following article:

Original Citation:

Availability:

This version is available http://hdl.handle.net/2318/1717337

since 2019-11-23T19:37:27Z

Publisher:

Geological Society of America

Published version:

DOI:10.1130/abs/2019AM-339775

Terms of use:

Open Access

Anyone can freely access the full text of works made available as "Open Access". Works made available under a Creative Commons license can be used according to the terms and conditions of said license. Use of all other works requires consent of the right holder (author or publisher) if not exempted from copyright protection by the applicable law. 


\section{Abstract \#339775}

\section{MÉLANGE CONCEPT: REDEFINITION AND A NEW CLASSIFICATION}

FESTA, Andrea, Università di Torino, Dipartimento Scienze della Terra, Via Valperga Caluso 35, Torino, 10125, Italy, DILEK, Yildirim, Department of Geology \& Environmental Earth Science, Miami University, 208 Shideler Hall, 250 South Patterson Avenue, Oxford, $\mathrm{OH}$ 45056, OGATA, Kei, Faculty of Science, Vrije Universiteit, De Boelelaan 1085, Amsterdam, 1081 HV, Netherlands and PINI, Gian Andrea, Dipartimento di Matematica e Geoscienze, Università degli Studi di Trieste, via Weiss 2, Trieste, 34128, Italy

Nearly 100 years after the introduction of the term "mélange" by Greenly (1919 Mem. Geological Survey, London), the definition of a mélange, the mode and nature of processes responsible for mélange formation, and the geological environments in which different mélange types form are still a topic of controversy. The main challenge in studies of mélanges is the recognition of their original, diagnostic block-in-matrix fabric elements, which provide critical clues for where and how these chaotic rock assemblages initially formed and what they tell us about the nature of and interplay between crustal and submarine processes during their development. Here, we present an overview of characteristic mélange types, discuss their formation and present a functional, new mélange classification. Using field-based stratigraphic and structural criteria, we show that mélanges are characterized and distinguished from each other by different internal fabrics and diagnostic block-in-matrix arrangements (Festa et al., 2019 Gondwana Research). Tectonic, sedimentary, and diapiric processes and their mutual interplay and superposition in various geological settings result in the formation of different mélange types (Festa et al., 2010 International Geology Review; Festa et al., 2016 Gondwana Research). Mélange forming processes can be spatially and temporally associated with extensional tectonics, passive margin evolution, strike-slip tectonics, convergent margin tectonics, collision tectonics, and intra-continental deformation. Hence, mélanges are not just restricted to subduction-accretion complexes in terms of their occurrence and formation. Redefinition of mélange, the new mélange classification and the evolving mélange concept, as presented here, provide important new constraints in solving some of the long-standing controversies in the literature. They can also be used effectively in reconstructing various paleoenvironments within different tectonic settings as recognized in the geological record.

Geological Society of America Abstracts with Programs. Vol. 51, No. 5, ISSN 0016-7592

doi: 10.1130/abs/2019AM-339775 @ Copyright 2019 The Geological Society of America (GSA), all rights reserved. 